\title{
Traumatic rupture of gastric pull-up after apparent mild thoracic trauma: a case report and literature review
}

\author{
Joaquin Valle, M.D., Hanumantha Srinivasrao, M.D., David Snow, M.D., Mike Asbitt, M.D.
}

Department of Emergency Medicine, Southport and Omskirk Hospital, Southport-United Kingdom

\begin{abstract}
While elderly patients account for only $10-12 \%$ of all trauma victims, they consume $25 \%$ of trauma-related health care resources, with higher rates of mortality and complication. Presently described is the case of an elderly patient who presented to the emergency department (ED) following mild thoracic trauma, with previous history of gastric pull-up surgery. The patient had consulted another facility 48 hours earlier and was prescribed analgesia and x-ray follow-up for a mechanical fall and pain in the lower rib cage.At arrival, the patient complained of increasing dyspnea and pain at the right hemithorax. X-ray showed right hemithorax effusion, and contrast computed tomography (CT) demonstrated a large amount of contrast filling the pleural space and a relatively small point of gastric pull-up rupture in the stomach. The patient was referred to the cardiothoracic unit, but was unresponsive upon arrival and died. The aim of the present report was to raise the index of clinical suspicion of traumatic rupture of the gastric pull-up following traumatic chest injury, and to affirm that contrast CT should be the gold standard for diagnosis.
\end{abstract}

Keywords: Elderly; gastric pull-up; trauma.

\section{INTRODUCTION}

Elderly patients with minor injuries and pre-existing medical conditions have increased risk of death, compared to their younger counterparts, and are more likely to die of medical complications late in hospital admission. Overall, $38 \%$ of all injury-related deaths occur in individuals aged 75 years and older among the ageing population, and these figures are likely to increase. Data from Western countries suggest an increase from $19 \%$ in 2010 to $23 \%$ in 2035 in the UK. ${ }^{[I]}$ Esophagectomy with gastric pull-up is a surgical procedure in which the stomach is used to replace the esophagus, and quality of life in patients who survive 10 or more years after esophagectomy and gastric pull-up is excellent. However, the number of patients presenting to emergency departments (EDs) with related complications will increase.

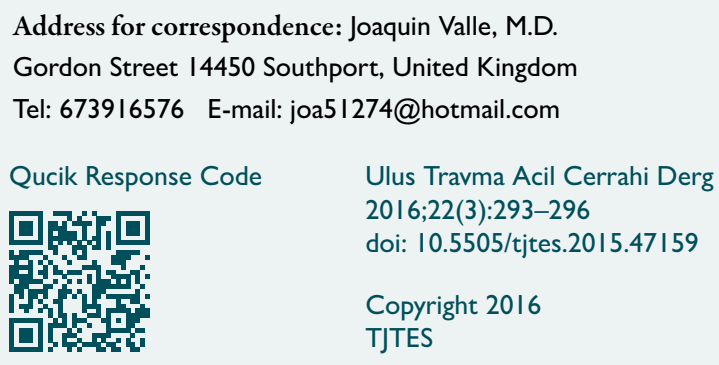

\section{CASE REPORT}

An 85-year-old man presented to the ED 2 days after sustaining a fall with blunt trauma to the lower right rib cage. The patient had been seen at a primary care facility after missing a step in the kitchen, falling backwards, and striking his chest against the corner of a chair. Tenderness at the eighth rib was elicited, and probable rib fracture was diagnosed. The patient was discharged under the care of his family and given a prescription for paracetamol with codeine (co-dydramol), with chest x-ray scheduled for 48 hours later. History included gastric pull-up for the treatment of esophageal adenocarcinoma 13 years prior, in addition to hypertension and transient ischemic attack. Treatment included aspirin $75 \mathrm{mg}$, omeprazole $40 \mathrm{mg}$, and bendroflumethiazide $2.5 \mathrm{mg}$. After 48 hours, the patient was transferred by ambulance to the accident and emergency department, with main complaint of severe stabbing right hemithorax pain and gradually worsening dyspnea; the pain was worse on inspiration. Upon arrival, the patient had dyspnea with use of accessory muscles, palpable regular pulses with a rate of $130 \mathrm{bpm}$, and arterial pressure of $110 / 60$ $\mathrm{mmHg}$. On pulse oximetry, saturation was $88 \%$ in room air. Glasgow Coma Scale score was I5.

Complete physical examination revealed tenderness over the right posterolateral chest wall with ecchymotic bruises. Breath sounds were absent in the right hemithorax. Abdominal and neurological examinations were unremarkable. 
Thoracic bedside ultrasound was consistent with pleural effusion, and Focused Assessment with Sonography for Trauma (FAST) scan was negative. Complete blood count, serum electrolytes, glucose, urea, and creatinine were normal, while electrocardiogram showed sinus tachycardia. Portable chest $x$-ray showed right hemithorax effusion (Fig. I). Arterial blood gases on admission were: $\mathrm{pH}$ 7.246; partial pressure of carbon dioxide: $49.3 \mathrm{mmHg}$; partial pressure of oxygen: 47 $\mathrm{mmHg}$; bicarbonate: $21.9 \mathrm{mEq} / \mathrm{L}$; oxygen saturation: $89.9 \%$; lactate: $2.1 \mathrm{mmol} / \mathrm{L}$. Further work-up included non-contrast thorax computed tomography (CT; Fig. I), which revealed a mixture of primarily fluid with some air in the pleural space, and with right lung compression. No rib fracture was present, though possible rupture in the gastric pull-up was indicated. Contrast CT was used assess the integrity of the esophagus and stomach (Fig. 2). It showed a large amount of contrast filling the pleural space, and a relatively small point of rupture in the stomach, posterolaterally. The patient was immediately referred to the cardiothoracic unit. Upon arrival, he went into respiratory distress (saturation: $75 \%$ on I5L of oxygen), and became hypotensive (blood pressure: 54 over $40 \mathrm{mmHg}$ ) and tachypneic (respiratory frequency: 24 breaths/minute). The patient became pulseless and asystolic, with fixed, dilated pupils. Resuscitation attempts failed, and the patient was pronounced dead. Ultimate diagnosis was traumatic rupture of the gastric pull-up with significant hydrothorax of gastric content.

\section{DISCUSSION}

As the elderly population within the UK continues to grow, ${ }^{[1]}$ more elderly patients will suffer trauma. While this growing number of elderly patients form a small percentage of overall trauma patients, they consume a disproportionate amount of medical resources ${ }^{[2]}$ and are more likely to require hospital admission. ${ }^{[3]}$ There has been an associated increase in the number of elderly major trauma patients presenting to EDs, without clear guidelines for the optimization of management of this vulnerable group. Aggressive early management of such patients results in increased survival rate, and of those who survive, the majority return home. ${ }^{[4]}$

Mortality due to trauma continues to fall, but the highest rates are seen in patients older than 65 years. The majority of traumas are secondary to falls. ${ }^{[5]}$ Elderly patients with minor injuries have increased risk of death, compared to their younger counterparts, and are more likely to die of medical complications late in hospital admission. The elderly undergo significant physiologic changes that disguise the normal stress response, such as arteriosclerotic arteries, reduced response
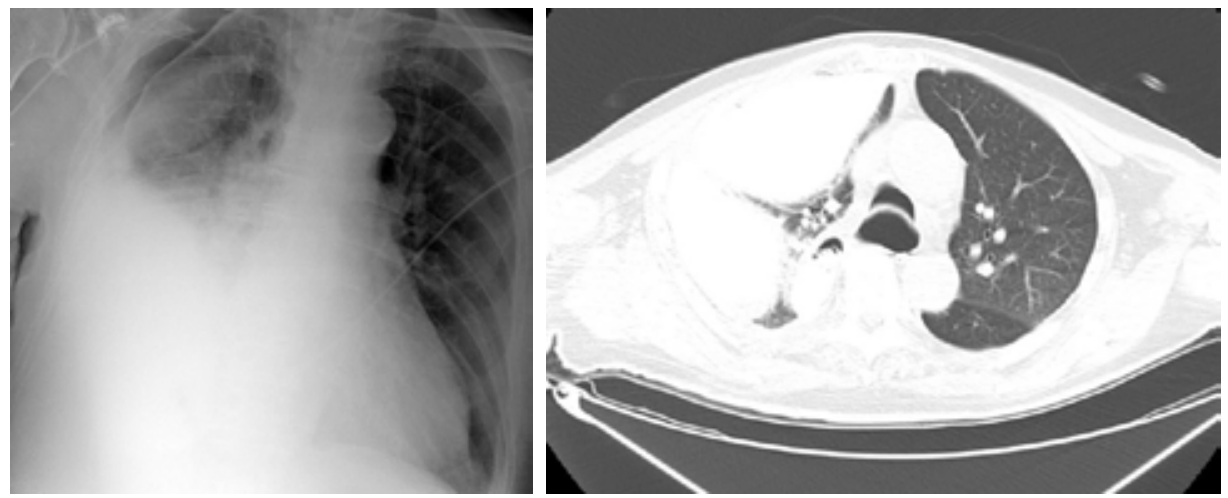

Figure 1. Chest $\mathrm{x}$-ray showing right hemithorax effusion, and non-contrast thorax computed tomography showing a mixture of primarily fluid with some air in the pleural space, and with right lung compression.
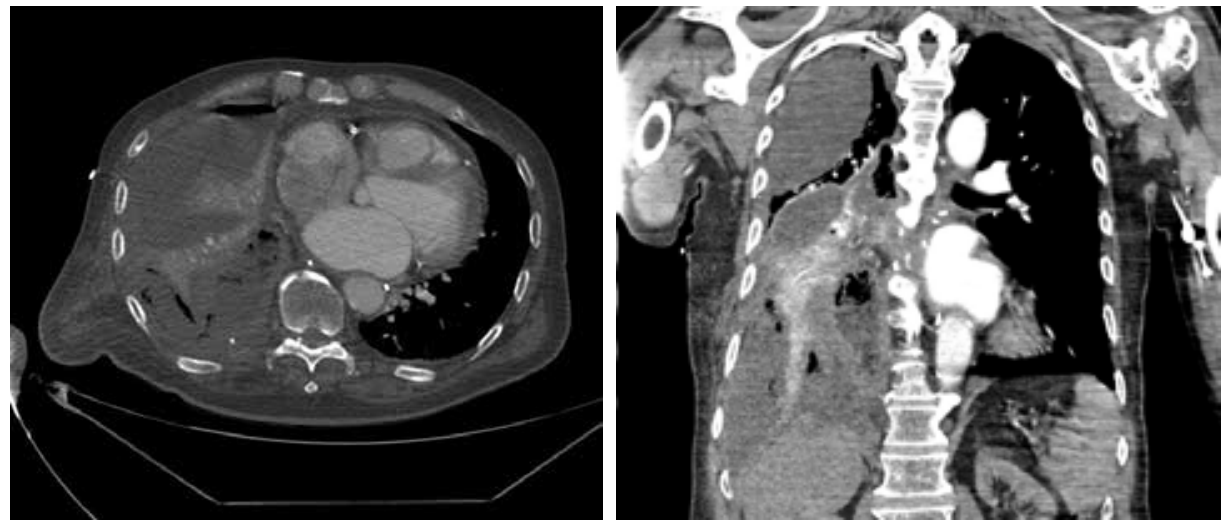

Figure 2. Traumatic rupture of the gastric pull-up with significant hydrothorax of gastric content, and, posterolaterally, a relatively small point of rupture in the stomach. 
to catecholamines, decreased cardiac output and myocardial contractility, muscular atrophy, decreased bone mass, and decreased lung compliance. Other influencing factors are preexisting illnesses, current medications, and the mechanism of injury. Injuries in older patients are more likely to have fatal outcome..$^{[6-8]}$ In one study, Shorr et al. ${ }^{[9]}$ reported a mortality rate that was 2.76 times higher in older victims of blunt chest trauma.

There is a significant association between severe preexisting medical disease and death during admission for trauma. A UK study analyzed the cases of 100 consecutive trauma patients 65 years of age and over that had been prospectively entered into the UK Trauma Network database from a single center. Of the 100 patients, 16 died and 84 survived. Eleven of the 16 who died and 12 of the survivors had preexisting medical disease and social dependency, suggesting poor outcome, as these factors are significantly associated with mortality. ${ }^{[10]}$ Elderly patients with isolated chest injuries have more than twice the mortality rate of younger patients with the same injuries. ${ }^{[l]}$

Esophagectomy with gastric pull-up is a surgical procedure in which the stomach is used to replace the esophagus. It is an integral part of the curative treatment of esophageal cancer, either as initial therapy or following preoperative chemoradiotherapy, and is also performed to treat end-stage benign conditions in some patients. Mortality and morbidity of esophagectomy and gastric pull-up for carcinoma of the esophagus is high. ${ }^{[12]}$ Patients who present with blunt thoracic trauma and previous gastric pull-up are rarely encountered in ED practice. However, it has recently been reported that quality of life in patients who survived 10 or more years following esophagectomy and gastric pull-up was excellent, matching or exceeding population normal values. ${ }^{[13]}$ Complications after gastric pull-up include anastomotic leak, pneumonitis, pleural effusion, wound infection, heart failure, anastomosis stricture, chylous fistula, hemothorax, hemoperitoneum, and burst abdomen.

Presently described was a geriatric patient with minor chest trauma seen at a primary care facility and treated for suspected rib fracture. Nevertheless, one of the most important aspects of this case was the history of gastric pull-up. No previous cases of traumatic pull-up rupture have been reported. One point of consideration is that patients with pull-up do not commonly present to the ED, though it has been demonstrated that patients who survive have a normal quality of life. ${ }^{\left[{ }^{13]}\right.}$ Therefore, in the future, more patients will be presenting to the ED with several conditions, including trauma. That a rupture of the gastric pull-up may occur should be taken into consideration, and contrast CT should be requested.
In the management of trauma in elderly patients, it is essential that clinicians compile an improved base of evidence to further inform our approach in this vulnerable group of patients. There are many barriers to the research and gathering of good evidence that will support clinical decision-making in the resuscitation environment. A diversity of approaches should be developed to treat trauma in elderly patients, even when minor, as pre-injury health status, management goals, treatment paradigms, and likely outcomes are very different. ${ }^{[14]}$ The present case serves as a useful reminder that there is less room for error when examining and treating older patients with blunt injuries to the chest.

Conflict of interest: None declared.

\section{REFERENCES}

1. Office for National Statistics, United Kingdom. Topic guide to Population estimates. Available at: http://www.statistics.gov.uk/hub/population/population-change/population-estimates/index.html.

2. MacKenzie EJ, Morris JA Jr, Smith GS, Fahey M. Acute hospital costs of trauma in the United States: implications for regionalized systems of care. J Trauma 1990;30:1096-103. Crossref

3. Court-Brown CM, Clement N. Four score years and ten: an analysis of the epidemiology of fractures in the very elderly. Injury 2009;40:1111-4.

4. Broos PL, D'Hoore A, Vanderschot P, Rommens PM, Stappaerts KH. Multiple trauma in elderly patients. Factors influencing outcome: importance of aggressive care. Injury 1993;24:365-8. Crossref

5. Griffiths $\mathrm{C}$, Wright $\mathrm{O}$, Rooney $\mathrm{C}$. Trends in injury and poisoning mortality using the ICE on injury statistics matrix, England and Wales, 1979. 2004. Health Stat Q 2006;32:5-18.

6. Evans R. Trauma and falls. In: Sanders AB, editor. Emergency care of the elder person. Philadelphia: Society for Academic Emergency Medicine, Beverly Cracom Publications; 1996. p. 153-70.

7. Levy DB, Hanlon DP, Townsend RN. Geriatric trauma. Clin Geriatr Med 1993;9:601-20.

8. Oreskovich MR, Howard JD, Copass MK, Carrico CJ. Geriatric trauma: injury patterns and outcome. J Trauma 1984;24:565-72. Crossref

9. Shorr RM, Rodriguez A, Indeck MC, Crittenden MD, Hartunian S, Cowley RA. Blunt chest trauma in the elderly. J Trauma 1989;29:234-7.

10. Pickering SA, Esberger D, Moran CG. The outcome following major trauma in the elderly. Predictors of survival. Injury 1999;30:703-6. Crossref

11. Taylor MD, Tracy JK, Meyer W, Pasquale M, Napolitano LM. Trauma in the elderly: intensive care unit resource use and outcome. J Trauma 2002;53:407-14. Crossref

12. Leers JM, DeMeester SR, Chan N, Ayazi S, Oezcelik A, Abate E, et al. Clinical characteristics, biologic behavior, and survival after esophagectomy are similar for adenocarcinoma of the gastroesophageal junction and the distal esophagus. J Thorac Cardiovasc Surg 2009;138:594-602.

13. Greene CL, DeMeester SR, Worrell SG, Oh DS, Hagen JA, DeMeester TR. Alimentary satisfaction, gastrointestinal symptoms, and quality of life 10 or more years after esophagectomy with gastric pull-up. J Thorac Cardiovasc Surg 2014;147:909-14. Crossref

14. Mitra B, Cameron PA. Optimising management of the elderly trauma patient. Injury 2012;43:973-5. Crossref 


\section{OLGU SUNUMU - ÖZET}

\section{Belirgin bir toraks travması ardından gastrik pull-up' ın travmatik rüptürü: Bir olgu raporu ve literatürün gözden geçirilmesi \\ Dr. Joaquin Valle, Dr. Hanumantha Srinivasrao, Dr. David Snow, Dr. Mike Asbitt}

Southport ve Omskirk Hastanesi, Acil Tıp Kliniği, Southport, İngiltere

Yaşlı hastalar tüm travmaya uğrayanların yalnızca \%।0-12'sini oluşturmasına rağmen göreceli yüksek mortalite ve komplikasyon oranlarıyla sağlık kaynaklarının \%25'ini tüketmektedirler. Bu yazıda, daha önce gastrik pull-up cerrahisi geçirmiş, hafif bir göğüs travması ardından acil servise (AS) başvuran yaşlı bir hasta sunuldu. Hasta 48 saat önce başka bir merkeze başvurmuş, düşme ve göğüs kafesi alt kısmındaki ağrısı için ağrı kesici reçetelendirilmiş ve radyolojik takip önerilmiş. Hasta acil servise vardığında giderek artan nefes darlı̆̆ ve sağ hemitoraksta ağrıdan yakınmıştır. Röntgende sağ hemitoraksta efüzyon, kontrastlı bilgisayarlı tomografide (BT) plevra boşluğunu dolduran büyük miktarda kontrast madde ve midede gastrik pull-up operasyon yerinde oldukça ufak bir rüptür görülmüştür. Hasta kardiyotorasik birime sevk edilmiş olmasına rağmen vardığında bilinç kaybı vardı ve yaşamını yitirmişti. Bu olgu sunumunun amacı, toraks travmasından sonra gastrik pull-up yerinde travmatik rüptürden yüksek derecede klinik kuşku duyulmasını sağlamak ve tanıda altın standardın mutlaka kontrastlı BT olduğunu doğrulamaktı.

Anahtar sözcükler: Gastrik pull-up; travma; yaşlılar.

Ulus Travma Acil Cerrahi Derg 2016;22(3):293-296 doi: 10.5505/tjtes.20I5.47I59 